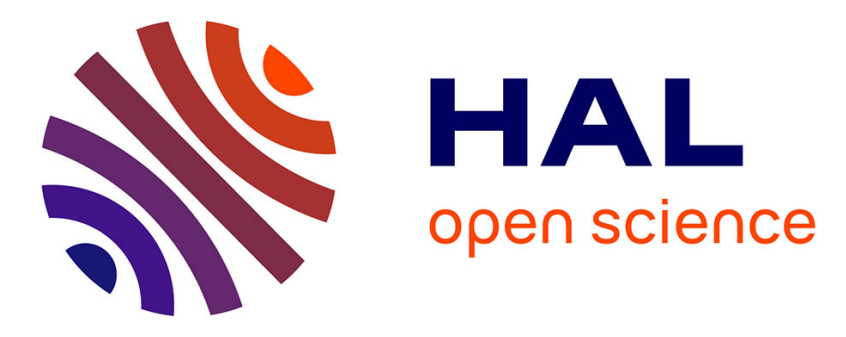

\title{
Rice height and biomass estimations using multitemporal SAR Sentinel-1: Camargue case study
}

Emile Ndikumana, Dinh Ho Tong Minh, Nicolas Baghdadi, Dominique

Courault, Laure Hossard

\section{- To cite this version:}

Emile Ndikumana, Dinh Ho Tong Minh, Nicolas Baghdadi, Dominique Courault, Laure Hossard. Rice height and biomass estimations using multitemporal SAR Sentinel-1: Camargue case study. SPIE Remote Sensing, Society of Photographic Instrumentation Engineers (SPIE). Cardiff, GBR., Sep 2018, Berlin, Germany. 1 p., 10.1117/12.2325174 . hal-02785362

\section{HAL Id: hal-02785362 \\ https: / hal.inrae.fr/hal-02785362}

Submitted on 4 Jun 2020

HAL is a multi-disciplinary open access archive for the deposit and dissemination of scientific research documents, whether they are published or not. The documents may come from teaching and research institutions in France or abroad, or from public or private research centers.
L'archive ouverte pluridisciplinaire HAL, est destinée au dépôt et à la diffusion de documents scientifiques de niveau recherche, publiés ou non, émanant des établissements d'enseignement et de recherche français ou étrangers, des laboratoires publics ou privés. 


\section{Rice height and biomass estimations using multitemporal SAR Sentinel-1: Camargue case study}

Paper 10783-31

Author(s): Emile Ndikumana, Dinh Ho Tong Minh, Nicolas Baghdadi, Institut National de Recherche en Sciences et Technologies Pour l'Environnment et l'Agriculture (France); Dominique Courault, Laure Hossard, Institut National de la Recherche Agronomique (France)

The development and improvement methods to follow agricultural growth is a timely challenge, especially for radar images. This is due to the speckle noise nature of radar, leading to a less intensive use of radar rather than optical images. Recently, the European Space Agency Sentinel-1 constellation is a satellite system providing the global coverage of Synthetic Aperture Radar (SAR) with a 6-days revisit period at a high spatial resolution about $20 \mathrm{~m}$. These data are valuable aids in providing the spatial information of agricultural crops. The aim of this paper is to analyze the potentialities of using Sentinel-1 radar images for rice biomass and height retrieval. The study is carried out on a multi-temporal Sentinel-1 dataset acquired from May 2017 to September 2017 over the Camargue region in the South-Easten France. Ground measurements were made in the same period to collect biomass and crop heights over 11 rice fields. The images were processed in order to produce an intensity radar data stack in $\mathrm{C}$ band including a dual polarization $\mathrm{VV}$ and $\mathrm{VH}$, resulting finally in 50 images for the studied period. Correlation analysis were made according to a multivariable regression which exploited not only the dual polarization information but also the day of sowing of rice practices for the stable inversion. We found that the SAR Sentinel-1 is strongly correlated to the rice height and biomass in the order of magnitude $\mathrm{R}^{\wedge} 2>0.9$ and the root mean square error was less than $15 \%$ for height and $16 \%$ for biomass. Such results confirm that the high qualified radar Sentinel-1 could be well exploited for rice biomass and height retrieval and could be used for operational tasks. 